Part of Journal of Research of the National Bureau of Standards, Volume 14, March 1935

\title{
STANDARD TABLES FOR CHROMEL-ALUMEL THERMOCOUPLES
}

\author{
By Wm. F. Roeser, A. I. Dahl, and G. J. Gowens
}

ABSTRACT

Tables have been prepared giving the thermal emf of chromel $\mathrm{P}$ vs alumel, chromel $\mathrm{P}$ vs platinum, and alumel vs platinum at various temperatures in the range -310 to $2,500^{\circ} \mathrm{F}$. The values in the range 0 to $2,500^{\circ} \mathrm{F}$ are based on the calibration of 15 representative no. 8 gage chromel-alumel thermocouples selected after preliminary tests on 50 heats of each alloy made by the method regularly used. The tables give the temperature-emf relation of the thermocouples now being manufactured as closely as the wires can be reproduced at the present time. The guarantee limits have been fixed by the manufacturer at $\pm 5^{\circ} \mathrm{F}$ in the range 0 to $660^{\circ} \mathrm{F}$ and to $\pm 3 / 4$ percent in the range 660 to $2,300^{\circ} \mathrm{F}$.

The methods used in calibrating the thermocouples in the various temperature ranges are briefly described.

CONTENTS

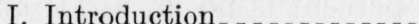

II. Materials

III. Test methods _.

IV. Results_.......... 242

\section{INTRODUCTION}

With the increasing use of pyrometric equipment and a more general realization of the value of careful temperature control of industrial processes, especially at high temperatures, has come a demand for increased accuracy in the measurement and control of temperatures by thermoelectric pyrometers. The number of such pyrometers employed is so great that it is not practicable to calibrate each thermocouple used to indicate, record, or control temperatures. Except in those cases where the highest accuracy is required, the users of pyrometers are dependent upon the manufacturer to supply thermocouples which give, within reasonable limits, corresponding temperature-emf values which are representative of the general product. These relations may be represented by curves or tables, but more generally they are incorporated in the graduation of the scales of direct-reading instruments. Some of the temperature-emf relations now in use are of such nature that it is difficult or impossible to make thermocouples to correspond to them. There are a number of tables published in catalogs, handbooks, and physical tables giving corresponding temperature-emf values for thermocouples, but it has not been demonstrated, except in the case of rare-metal thermo- 
couples, ${ }^{1}$ that any of these tables represent, to the accuracy demanded, the temperature-emf relation of the couples now being manufactured.

The variety of tables used for chromel-alumel has not been as great as for other types of base-metal couples, because there has never been more than one manufacturer of this type of couple. Although the differences among the various tables published in the past twenty years for chromel-alumel thermocouples are not large, they are greater than the errors permissible in many industrial and technical processes. These differences cannot be attributed entirely to variations in the characteristics of the thermocouples as produced at various times. Many of them are due to the methods of arriving at the tables; for example, as concerns the accuracy of the measurements, number of observations, number of thermocouples used, and the degree to which the material tested was representative of the general product.

At the request of a number of pyrometer users and instrument manufacturers, and in cooperation with the Hoskins Manufacturing Co., the present investigation was conducted at the National Bureau of Standards to determine a representative temperature-emf relation for the chromel-alumel thermocouples now being manufactured.

\section{MATERIALS}

The nominal composition of the chromel $\mathrm{P}$ alloy is 90-percent nickel and 10-percent chromium. Alumel contains approximately 95 percent nickel, with aluminum, silicon, and manganese making up the other 5 percent.

Approximately 80 percent of the chromel $\mathrm{P}$ and alumel used in thermocouples is no. 8 gage wire and 95 percent is no. $6,8,11$, and 14 gage wire. As the shape of the temperature-emf curve is apparently independent of the size of the wire, only no. 8 gage wire was used in the present work. The manufacturer selected 30 samples of no. 8 gage wire from 100 heats of chromel $P$ and alumel. In order that the completed thermocouples should be typical of the general product, all of this wire was heat treated and "matched" by the manufacturer in the same manner as all the chromel $\mathrm{P}$ and alumel wire regularly supplied to pyrometer users. The process of matching consists in measuring the thermal emf of each lot of chromel $\mathrm{P}$ and of alumel against pure platinum at one or more selected temperatures, and then combining the lots of chromel $\mathrm{P}$ and of alumel so that the completed thermocouples will develop a predetermined emf at certain temperatures. In this process, the standard value to which the manufacturer has always worked is 36.20 millivolts (abbreviated hereafter $\mathrm{mv}$ ) when one junction of the thermocouple is at $32^{\circ} \mathrm{F}$ and the other at $1,600^{\circ} \mathrm{F}$.

\section{TEST METHODS}

In addition to determining the temperature-emf relation for chromel $P$ against alumel, similar relations were also determined for each element against pure platinum. All the thermal-emf values of the individual elements were referred to the platinum standard, $\mathrm{Pt} 27$, maintained at the National Bureau of Standards. This platinum standard is spectroscopically pure and has been thoroughly annealed, and although it may not be the purest platinum that has been or will

1 BS J. Research 10, 275 (1933) RP530. 
be prepared, it has served as a satisfactory arbitrary standard against which the thermal emf of other materials may be measured. The platinum working standards used in this investigation were checked against the standard $\mathrm{Pt} 27$ before and after the calibration of each of the chromel-alumel thermocouples. The thermal emf of the working platinum standards did not change more than the uncertainty of the measurements (about $2 \mu \mathrm{v}$ ) during any series of measurements. The accuracy of the measurements of chromel $\mathrm{P}$ and of alumel against platinum does not in any way affect the results obtained for chromel $\mathrm{P}$ against alumel. The sum of the values of thermal emf for chromel $\mathrm{P}$ against any material (A) and of alumel against the same material (A) must equal the value for chromel $\mathrm{P}$ against alumel, and as all three were measured in this work any two serve as a check upon the third.

The chromel $\mathrm{P}$ and alumel wires, insulated by 2 -hole porcelain insulators, and the platinum wire, protected by a glazed porcelain tube, were all welded together at the hot junction. The platinum wire was sealed through the end of the protection tube with a pyrex glass, leaving about $1 \mathrm{~cm}$ of the platinum wire between the seal and the welded junction.

In the temperature range $0^{\circ} \mathrm{F}$ to room temperature, the thermocouples were calibrated by comparison with mercury-in-glass standard thermometers in a stirred liquid bath cooled by a carbon-dioxide refrigerating system. In the range room temperature to $1,000^{\circ} \mathrm{F}$, the thermocouples were calibrated by comparison with a standard platinum-resistance thermometer. The thermometer and thermocouple were placed to the same depth in holes drilled in an insulated copper block which was heated electrically. The couples were then calibrated in the range 500 to $2,500^{\circ} \mathrm{F}$ by comparison with standard platinum to platinum-10 percent rhodium thermocouples in a platinum-wound porcelain-tube furnace, $60 \mathrm{~cm}$ long and $2.5 \mathrm{~cm}$ in diameter. The standard thermocouple wires were insulated with a 2-hole porcelain tube inside a glazed porcelain protection tube. The hot junction end of the thermocouple was sealed through the end of the protection tube with a pyrex glass, leaving about $2 \mathrm{~mm}$ of the thermocouple protruding. The hot junction of the platinum-rhodium thermocouple was inserted in a hole about $1.5 \mathrm{~mm}$ in diameter, drilled in the hot junction formed by welding the chromel $\mathrm{P}$, alumel and platinum wires.

In all the comparisons with the various types of standards, the cold junctions were maintained at $32^{\circ} \mathrm{F}$ and the depth of immersion of the chromel-alumel thermocouples in the bath or furnace was 30 $\mathrm{cm}$. All the emf measurements were made with potentiometers. During an observation, the temperature of the bath or furnace was maintained practically constant and the standards were read before and after the observations of the emf of the chromel $\mathrm{P}$ vs alumel, chromel $\mathrm{P}$ vs platinum and alumel vs platinum. The first thermocouple was calibrated at intervals of $10^{\circ}$ in the range 0 to $100^{\circ} \mathrm{F}$, $20^{\circ}$ in the range 100 to $600^{\circ} \mathrm{F}, 50^{\circ}$ in the range 600 to $1,000^{\circ} \mathrm{F}$, and $100^{\circ}$ above $1,000^{\circ} \mathrm{F}$. It was then easily shown that the curves were sufficiently smooth that the accuracy required could be obtained by calibration at intervals of $50^{\circ}$ in the range 0 to $1,000^{\circ} \mathrm{F}$ and of $100^{\circ}$ 
above $1,000^{\circ} \mathrm{F}$. Observations were therefore taken on the remaining thermocouples only at these temperature intervals.

The mercury-in-glass and platinum-resistance thermometers and the platinum-rhodium thermocouples used as standards were either calibrated in accordance with the specifications of the International Temperature Scale ${ }^{2}$ or by comparison with other instruments which had been so calibrated. It is estimated that the accuracy of the measurements and the intervals between observation points were such that the uncertainty in the determination of the corresponding values of temperature and emf for each of the 15 couples does not exceed $0.5^{\circ}$ in the range 0 to $500^{\circ} \mathrm{F}, 1^{\circ}$ in the range 500 to $1,000^{\circ} \mathrm{F}$, $2^{\circ}$ in the range 1,000 to $2,000^{\circ} \mathrm{F}$, and $4^{\circ}$ above $2,000^{\circ} \mathrm{F}$.

\section{RESULTS}

Most of the chromel $\mathrm{P}$ wire produced gives $28.50 \pm 0.10 \mathrm{mv}$ against platinum when one junction is at $32^{\circ} \mathrm{F}$ and the other at $1,600^{\circ} \mathrm{F}$. Similarly most of the alumel wire gives $-7.70 \pm 0.10 \mathrm{mv}$ against platinum when the junctions are at $32^{\circ} \mathrm{F}$ and $1,600^{\circ} \mathrm{F}$. As mechanical working and small changes in the chemical composition have an appreciable effect upon the thermal emf, it is difficult to control all of the final product to these limits, particularly the wires of the smaller diameters. In the event that all the wire does not fall within the above limits, the chromel $\mathrm{P}$ wire giving $28.30 \pm 0.10 \mathrm{mv}$ is combined with alumel giving $-7.90 \pm 0.10 \mathrm{mv}$ and the chromel $\mathrm{P}$ wire 28.70 $\pm 0.10 \mathrm{mv}$ is combined with alumel giving $-7.50 \pm 0.10 \mathrm{mv}$. In any case the completed thermocouple gives $36.20 \pm 0.20 \mathrm{mv}$ when one junction is at $32^{\circ} \mathrm{F}$ and the other at $1,600^{\circ} \mathrm{F}$. The differences between the shapes of the temperature-emf curves of the thermocouples made by matching the various elements in this way are small compared to the limits within which the manufacturer guarantees to reproduce the standard temperature-emf values. For example, a sample of chromel giving $28.40 \mathrm{mv}$ against platinum when combined with a sample of alumel giving $-7.80 \mathrm{mv}$ gives practically the same temperature-emf values as a sample of chromel giving $28.60 \mathrm{mv}$ against platinum when combined with a sample of alumel giving $-7.60 \mathrm{mv}$. The temperatureemf values for two such thermocouples are given in table 1 .

TABLE 1.-Comparison of two chromel-alumel thermocouples

\begin{tabular}{|c|c|c|c|c|c|c|}
\hline \multirow[b]{2}{*}{ Temperature ${ }^{\circ} \mathrm{F}$} & \multicolumn{6}{|c|}{ Electromotive force } \\
\hline & $\begin{array}{l}\text { Chromel } \\
130 \text { vs Pt }\end{array}$ & $\begin{array}{l}\text { Chromel } \\
171 \mathrm{vs} \mathrm{Pt}\end{array}$ & $\begin{array}{c}\text { Alumel } \\
86 \text { vs Pt }\end{array}$ & $\begin{array}{c}\text { Alumel } \\
4620 \mathrm{vs} \mathrm{Pt}\end{array}$ & $\begin{array}{l}\text { Chromel } \\
130 \mathrm{vs} \\
\text { alumel } 86\end{array}$ & $\begin{array}{c}\text { Chromel } \\
171 \text { vs } \\
\text { alumel } 4620\end{array}$ \\
\hline $\begin{array}{l}32 \\
500 \\
1,000 \\
1,600 \\
2,000 \\
2,500\end{array}$ & $\begin{array}{l}\mathrm{mv} \\
0.00 \\
7.95 \\
17.45 \\
28.42 \\
35.26 \\
43.15\end{array}$ & $\begin{array}{r}\mathrm{mv} \\
0.00 \\
8.00 \\
17.53 \\
28.60 \\
35.50 \\
43.46\end{array}$ & $\begin{array}{l}\mathrm{mv} \\
0.00 \\
-2.62 \\
-4.81 \\
-7.78 \\
-9.61 \\
-11.66\end{array}$ & $\begin{array}{r}\text { mv } \\
0.00 \\
-2.58 \\
-4.71 \\
-7.60 \\
-9.38 \\
-11.34\end{array}$ & $\begin{array}{r}\mathrm{mv} \\
0.00 \\
10.57 \\
22.26 \\
36.20 \\
44.87 \\
54.81\end{array}$ & $\begin{array}{r}\mathrm{m} \nabla \\
0.00 \\
10.58 \\
22.24 \\
36.20 \\
44.88 \\
54.80\end{array}$ \\
\hline
\end{tabular}

${ }^{2}$ BS J. Research 1, 635 (1928) RP22. 
Of the 15 thermocouples calibrated, 11 were made of chromel $\mathrm{P}$ giving $28.50 \pm 0.10 \mathrm{mv}$ and of alumel giving $-7.70 \pm 0.10 \mathrm{mv}$ against platinum at $1,600^{\circ} \mathrm{F}$. The other 4 thermocouples were made up of samples giving the following emf against platinum at $1,600^{\circ} \mathrm{F}: 28.82$ and $-7.38,28.77$ and $-7.42,28.29$ and -7.82 , and 28.21 and -7.82 .

In establishing the temperature-emf relation which is representative of the product now being supplied by the manufacturer, it makes very little difference whether the average of the results obtained on only the 11 thermocouples made of samples giving $28.50 \pm 0.10$ and -.7 .70$ $\pm 0.10 \mathrm{mv}$ against platinum at $1,600^{\circ} \mathrm{F}$ is used or whether the average of the results obtained on all the samples calibraced is used. The maximum difference would be less than $0.01 \mathrm{mv}\left(0.5^{\circ} \mathrm{F}\right)$.

The calibrations of the 11 thermocouples were averaged, giving values of the emf at various temperatures. The average emf at $1,600^{\circ} \mathrm{F}$ was $36.206 \mathrm{mv}$. Since all the previous tables issued by the manufacturer of chromel-alumel thermocouples have contained the value $36.20 \mathrm{mv}$ at $1,600^{\circ} \mathrm{F}$, this value was retained in the present table. The average values of the emf at the other temperatures were decreased by amounts equal to $e \times \frac{0.006}{36.20}$. This correction factor of $0.006 \mathrm{mv}$ at $1,600^{\circ} \mathrm{F}$ is equivalent to about $0.3^{\circ} \mathrm{F}$. The corrected values of the emf at the various temperatures were then used as the basis for tables 2 and 3 . These tables give the temperature-emf equivalents for chromel-alumel thermocouples in degrees Fahrenheit and in degrees centigrade at $10^{\circ}$ intervals. The values between the observed points were obtained by interpolation.

The fact that the individual couples were calibrated with an accuracy of from 0.5 to $4^{\circ} \mathrm{F}$ and that the difference between the calibrations given in table 1 is $1^{\circ} \mathrm{F}$ or less, does not mean that all chromelalumel thermocouples will give the temperature-emf relation in table 2 or 3 to this accuracy. The manufacturer guarantees only that the couples give these values within the following limits, $\pm 5^{\circ} \mathrm{F}$ in the range 32 to $660^{\circ} \mathrm{F}$ and to $\pm 3 / 4$ percent between 660 and $2,300^{\circ} \mathrm{F}$. All the couples calibrated in this investigation gave the temperatureemf values in tables 2 and 3 within these guaranteed limits.

The data available indicate that the temperature-emf values in tables 2 and 3 also apply for other sizes of wire. Data were obtained on no. 28 gage wire in the present work and on other sizes from a large number of routine calibrations made at this Bureau over a period of years. However, in the cases of nos. 22 and 28 gage thermocouple wire, the manufacturer's guarantee extends only to $1,600^{\circ} \mathrm{F}$, while for no. 18 gage and larger, it extends to $2,000^{\circ} \mathrm{F}$, and for no. 11 and larger to $2,300^{\circ} \mathrm{F}$.

The difference curves constructed by plotting the emf vs the differences between the calibrations of the individual couples and values in table 2 or 3 approximated straight lines for most of the couples composed of elements giving $28.50 \pm 0.10$ and $-7.70 \pm 0.10 \mathrm{mv}$ against platinum at $1,600^{\circ} \mathrm{F}$. The curve giving the difference between the calibration of any of the thermocouples and values in tables 2 and 3 is completely determined by calibration at $1,000,1,600$, and $2,000^{\circ} \mathrm{F}$. 
TABLE 2.-Standard Fahrenheit table for chromel-alumel thermocouples

\begin{tabular}{|c|c|c|c|c|c|c|c|c|c|c|c|}
\hline \multirow{2}{*}{ Temperature ${ }^{\circ} \mathrm{F}$} & \multicolumn{11}{|c|}{ Electromotive force in millivolts (reference junction at $32^{\circ} \mathrm{F}$ ) } \\
\hline & 0 & 10 & 20 & 30 & 40 & 50 & 60 & 70 & 80 & 90 & 100 \\
\hline $\begin{array}{l}0 \\
100 \\
200 \\
300 \\
400 \\
500\end{array}$ & $\begin{array}{r}-0.68 \\
1.52 \\
3.82 \\
6.09 \\
8.31 \\
10.56\end{array}$ & $\begin{array}{r}-0.47 \\
1.74 \\
4.05 \\
6.31 \\
8.53 \\
10.79\end{array}$ & $\begin{array}{r}-0.26 \\
1.97 \\
4.28 \\
6.53 \\
8.76 \\
11.02\end{array}$ & $\begin{array}{r}-0.04 \\
2.20 \\
4.51 \\
6.75 \\
8.98 \\
11.25\end{array}$ & $\begin{array}{r}+0.18 \\
2.43 \\
4.74 \\
6.98 \\
9.20 \\
11.47\end{array}$ & $\begin{array}{r}0.40 \\
2.66 \\
4.97 \\
7.20 \\
9.43 \\
11.70\end{array}$ & $\begin{array}{r}0.62 \\
2.89 \\
5.19 \\
7.42 \\
9.66 \\
11.93\end{array}$ & $\begin{array}{r}0.84 \\
3.12 \\
5.42 \\
7.64 \\
9.88 \\
12.16\end{array}$ & $\begin{array}{r}1.06 \\
3.36 \\
5.64 \\
7.87 \\
10.11 \\
12.39\end{array}$ & $\begin{array}{r}1.29 \\
3.59 \\
5.87 \\
8.09 \\
10.33 \\
12.62\end{array}$ & $\begin{array}{r}1.52 \\
3.82 \\
6.09 \\
8.31 \\
10.56 \\
12.85\end{array}$ \\
\hline $\begin{array}{l}600 \\
700 \\
800 \\
900 \\
1,000\end{array}$ & $\begin{array}{l}12.85 \\
15.18 \\
17.52 \\
19.88 \\
22.25\end{array}$ & $\begin{array}{l}13.08 \\
15.41 \\
17.75 \\
20.12 \\
22.49\end{array}$ & $\begin{array}{l}13.31 \\
15.64 \\
17.99 \\
20.36 \\
22.72\end{array}$ & $\begin{array}{l}13.55 \\
15.88 \\
18.22 \\
20.59 \\
22.96\end{array}$ & $\begin{array}{l}13.78 \\
16.11 \\
18.46 \\
20.83 \\
23.20\end{array}$ & $\begin{array}{l}14.01 \\
16.35 \\
18.70 \\
21.07 \\
23.43\end{array}$ & $\begin{array}{l}14.24 \\
16.58 \\
18.93 \\
21.30 \\
23.67\end{array}$ & $\begin{array}{l}14.48 \\
16.82 \\
19.17 \\
21.54 \\
23.91\end{array}$ & $\begin{array}{l}14.71 \\
17.05 \\
19.41 \\
21.78 \\
24.14\end{array}$ & & $\begin{array}{l}15.18 \\
17.52 \\
19.88 \\
22.25 \\
24.62\end{array}$ \\
\hline $\begin{array}{l}1,300 \\
1,400 \\
1,500\end{array}$ & $\begin{array}{l}24.62 \\
26.98 \\
29.33 \\
31.65 \\
33.94\end{array}$ & $\begin{array}{l}24.85 \\
27.21 \\
29.56 \\
31.88 \\
34.17\end{array}$ & $\begin{array}{l}25.09 \\
27.45 \\
29.79 \\
32.11 \\
34.40\end{array}$ & $\begin{array}{l}25.33 \\
27.68 \\
30.02 \\
32.34 \\
34.62\end{array}$ & $\begin{array}{l}25.57 \\
27.92 \\
30.26 \\
32.57 \\
34.85\end{array}$ & $\begin{array}{l}25.80 \\
28.15 \\
30.49 \\
32.80 \\
35.08\end{array}$ & $\begin{array}{l}26.04 \\
28.39 \\
30.72 \\
33.03 \\
35.30\end{array}$ & $\begin{array}{l}26.27 \\
28.62 \\
30.96 \\
33.26 \\
35.53\end{array}$ & $\begin{array}{l}26.51 \\
28.86 \\
31.19 \\
33.49 \\
35.75\end{array}$ & $\begin{array}{l}26.74 \\
29.09 \\
31.42 \\
33.71 \\
35.98\end{array}$ & $\begin{array}{l}26.98 \\
29.33 \\
31.65 \\
33.94 \\
36.20\end{array}$ \\
\hline $\begin{array}{l}1,800 \\
1,900 \\
2,000\end{array}$ & $\begin{array}{l}36.20 \\
38.43 \\
40.62 \\
42.77 \\
44.89\end{array}$ & $\begin{array}{l}36.42 \\
38.65 \\
40.83 \\
42.98 \\
45.10\end{array}$ & $\begin{array}{l}36.65 \\
38.87 \\
41.05 \\
43.20 \\
45.31\end{array}$ & $\begin{array}{l}36.87 \\
39.09 \\
41.27 \\
43.41 \\
45.52\end{array}$ & $\begin{array}{l}37.10 \\
39.31 \\
41.48 \\
43.62 \\
45.73\end{array}$ & $\begin{array}{l}37.32 \\
39.53 \\
41.70 \\
43.83 \\
45.93\end{array}$ & $\begin{array}{l}37.54 \\
39.75 \\
41.91 \\
44.04 \\
46.14\end{array}$ & $\begin{array}{l}37.76 \\
39.96 \\
42.13 \\
44.26 \\
46.35\end{array}$ & $\begin{array}{l}37.99 \\
40.18 \\
42.34 \\
44.47 \\
46.56\end{array}$ & $\begin{array}{l}38.21 \\
40.40 \\
42.56 \\
44.68 \\
46.76\end{array}$ & $\begin{array}{l}38.43 \\
40.62 \\
42.77 \\
44.89 \\
46.97\end{array}$ \\
\hline $\begin{array}{l}2,100 \\
2,200 \\
2,300 \\
2,400 \\
2,500\end{array}$ & $\begin{array}{l}46.97 \\
49.01 \\
51.00 \\
52.95 \\
54.85\end{array}$ & $\begin{array}{l}47.18 \\
49.21 \\
51.20 \\
53.14\end{array}$ & $\begin{array}{l}47.38 \\
49.41 \\
51.39 \\
53.33\end{array}$ & $\begin{array}{l}47.59 \\
49.61 \\
51.59 \\
53.52\end{array}$ & $\begin{array}{l}47.79 \\
49.81 \\
51.78 \\
53.71\end{array}$ & $\begin{array}{l}47.99 \\
50.01 \\
51.98 \\
53.90\end{array}$ & $\begin{array}{l}48.20 \\
50.21 \\
52.17 \\
54.09\end{array}$ & $\begin{array}{l}48.40 \\
50.41 \\
52.37 \\
54.28\end{array}$ & $\begin{array}{l}48.61 \\
50.61 \\
52.56 \\
54.47\end{array}$ & $\begin{array}{l}48.81 \\
50.80 \\
52.75 \\
54.66\end{array}$ & $\begin{array}{l}49.01 \\
51.00 \\
52.95 \\
54.85\end{array}$ \\
\hline
\end{tabular}

TABLE 3.-Standard centigrade table for chromel-alumel thermocouples

\begin{tabular}{|c|c|c|c|c|c|c|c|c|c|c|c|}
\hline \multirow{2}{*}{ Temperature ${ }^{\circ} \mathrm{C}$} & \multicolumn{11}{|c|}{ Electromotive force in millivolts (reference junction at $0^{\circ} \mathrm{C}$ ) } \\
\hline & 0 & 10 & 20 & 30 & 40 & 50 & 60 & 70 & 80 & 90 & 100 \\
\hline $\begin{array}{l}0 \\
100 \\
200 \\
300 \\
400 \\
40\end{array}$ & $\begin{array}{r}0.00 \\
4.10 \\
8.13 \\
12.21 \\
16.39\end{array}$ & $\begin{array}{r}0.40 \\
4.51 \\
8.53 \\
12.62 \\
16.82\end{array}$ & $\begin{array}{r}0.80 \\
4.92 \\
8.93 \\
13.04 \\
17.24\end{array}$ & $\begin{array}{r}1.20 \\
5.33 \\
9.34 \\
13.45 \\
17.66\end{array}$ & $\begin{array}{r}1.61 \\
5.73 \\
9.74 \\
13.87 \\
18.08\end{array}$ & $\begin{array}{r}2.02 \\
6.13 \\
10.15 \\
14.29 \\
18.50\end{array}$ & $\begin{array}{r}2.43 \\
6.53 \\
10.56 \\
14.71 \\
18.93\end{array}$ & $\begin{array}{r}2.85 \\
6.93 \\
10.97 \\
15.13 \\
19.36\end{array}$ & $\begin{array}{r}\text { 3. } 26 \\
7.33 \\
11.38 \\
15.55 \\
19.78\end{array}$ & $\begin{array}{r}3.68 \\
7.73 \\
11.80 \\
15.97 \\
20.21\end{array}$ & $\begin{array}{r}4.10 \\
8.13 \\
12.21 \\
16.39 \\
20.64\end{array}$ \\
\hline $\begin{array}{l}500 \\
7000 \\
800 \\
900\end{array}$ & $\begin{array}{l}20.64 \\
24.90 \\
29.14 \\
33.31 \\
37.36\end{array}$ & $\begin{array}{l}21.07 \\
25.33 \\
29.56 \\
33.71 \\
37.76\end{array}$ & $\begin{array}{l}21.49 \\
25.75 \\
29.98 \\
34.12 \\
38.16\end{array}$ & $\begin{array}{l}21.92 \\
26.18 \\
30.40 \\
34.53 \\
38.56\end{array}$ & $\begin{array}{l}22.34 \\
26.60 \\
30.82 \\
34.94 \\
38.96\end{array}$ & $\begin{array}{l}22.77 \\
27.03 \\
31.23 \\
35.35 \\
39.35\end{array}$ & $\begin{array}{l}23.20 \\
27.45 \\
31.65 \\
35.75 \\
39.75\end{array}$ & $\begin{array}{l}23.62 \\
27.87 \\
32.07 \\
36.16 \\
40.14\end{array}$ & $\begin{array}{l}24.05 \\
28.29 \\
32.48 \\
36.56 \\
40.53\end{array}$ & $\begin{array}{l}24.48 \\
28.72 \\
32.90 \\
36.96 \\
40.92\end{array}$ & $\begin{array}{l}24.90 \\
29.14 \\
33.31 \\
37.36 \\
41.31\end{array}$ \\
\hline $\begin{array}{l}1,000 \\
1,100 \\
1,300 \\
1,400\end{array}$ & $\begin{array}{l}41.31 \\
45.14 \\
48.85 \\
52.41 \\
55.81\end{array}$ & $\begin{array}{l}41.70 \\
45.52 \\
49.21 \\
52.75\end{array}$ & $\begin{array}{l}42.08 \\
45.89 \\
49.57 \\
53.10\end{array}$ & $\begin{array}{l}42.47 \\
46.27 \\
49.94 \\
53.45\end{array}$ & $\begin{array}{l}42.86 \\
46.64 \\
50.29 \\
53.79\end{array}$ & $\begin{array}{l}43.24 \\
47.01 \\
50.65 \\
54.13\end{array}$ & $\begin{array}{l}43.62 \\
47.38 \\
51.00 \\
54.47\end{array}$ & $\begin{array}{l}44.00 \\
47.75 \\
51.36 \\
54.81\end{array}$ & \begin{tabular}{|l|}
44.38 \\
48.12 \\
51.71 \\
55.15
\end{tabular} & $\begin{array}{l}44.76 \\
48.48 \\
52.06 \\
55.48\end{array}$ & $\begin{array}{l}45.14 \\
48.85 \\
52.41 \\
55.81\end{array}$ \\
\hline
\end{tabular}

It is believed that the values given in tables 2 and 3 are more representative than any that have been previously published for chromel-alumel thermocouples. These tables make possible more accurate temperature measurements with these thermocouples. The thermocouple alloys and their characteristics have not been changed, and consequently the scales and charts now in use can be used with the same accuracy as in the past.

Tables 4 and 5 giving the emf of chromel $\mathrm{P}$ vs platinum and alumel vs platinum were prepared in a similar manner using the data on the same samples as used in preparing tables 2 and 3 . The average 
value of emf for the chromel $\mathrm{P}$ samples against platinum was corrected so as to give $28.50 \mathrm{mv}$ at $1,600^{\circ} \mathrm{F}$, and that for alumel against platinum corrected so as to give $-7.70 \mathrm{mv}$ at $1,600^{\circ} \mathrm{F}$. Only the emf values at every $100^{\circ} \mathrm{F}$ and every $50^{\circ} \mathrm{C}$ are given here.

TABLE 4.-Thermal emf of chromel $\mathrm{P}$ and of alumel vs platinum

\begin{tabular}{|c|c|c|c|c|c|}
\hline \multirow{2}{*}{$\begin{array}{c}\text { Tempera- } \\
\text { ture }\end{array}$} & \multicolumn{2}{|c|}{$\begin{array}{l}\text { Electromotive force } \\
\text { (reference junction } \\
\text { at } 32^{\circ} \mathrm{F} \text { ) }\end{array}$} & \multirow{2}{*}{$\begin{array}{c}\text { Tempera- } \\
\text { ture }\end{array}$} & \multicolumn{2}{|c|}{$\begin{array}{l}\text { Electromotive force } \\
\text { (reference junction } \\
32^{\circ} \mathrm{F} \text { ) }\end{array}$} \\
\hline & $\begin{array}{c}\text { Chromel } \\
\text { P-platinum }\end{array}$ & $\begin{array}{l}\text { Alumel- } \\
\text { platinum }\end{array}$ & & $\begin{array}{c}\text { Chromel } \\
\text { P-platinum }\end{array}$ & $\begin{array}{l}\text { Alumel- } \\
\text { platinum }\end{array}$ \\
\hline $\begin{array}{r}{ }^{\circ} \mathrm{F} \\
0 \\
100 \\
200 \\
300 \\
400\end{array}$ & $\begin{array}{r}\text { Millivolts } \\
-0.44 \\
1.01 \\
2.61 \\
4.32 \\
6.11\end{array}$ & $\begin{array}{c}\text { Millivolts } \\
+0.24 \\
-.51 \\
-1.21 \\
-1.77 \\
-2.20\end{array}$ & $\begin{array}{l}{ }^{\circ} \mathrm{F} \\
1,500 \\
1,600 \\
1,700 \\
1,800 \\
1,900\end{array}$ & $\begin{array}{c}\text { Millivolts } \\
26.73 \\
28.50 \\
30.25 \\
31.98 \\
33.68\end{array}$ & $\begin{array}{c}\text { Millivolts } \\
-7.21 \\
-7.70 \\
-8.18 \\
-8.64 \\
-9.09\end{array}$ \\
\hline $\begin{array}{l}500 \\
600 \\
700 \\
800 \\
900\end{array}$ & $\begin{array}{r}7.96 \\
9.85 \\
11.76 \\
13.67 \\
15.59\end{array}$ & $\begin{array}{l}-2.60 \\
-3.00 \\
-3.42 \\
-3.85 \\
-4.29\end{array}$ & $\begin{array}{l}2,000 \\
2,100 \\
2,200 \\
2,300 \\
2,400\end{array}$ & $\begin{array}{l}35.36 \\
37.01 \\
38.64 \\
40.23 \\
41.78\end{array}$ & $\begin{array}{l}-9.53 \\
-9.96 \\
-10.37 \\
-10.77 \\
-11.17\end{array}$ \\
\hline $\begin{array}{l}1,000 \\
1,100 \\
1,200 \\
1,300 \\
1,400\end{array}$ & $\begin{array}{l}17.50 \\
19.39 \\
21.26 \\
23.11 \\
24.93\end{array}$ & $\begin{array}{l}-4.75 \\
-5.23 \\
-5.72 \\
-6.22 \\
-6.72\end{array}$ & 2,500 & 43.28 & -11.57 \\
\hline
\end{tabular}

TABLE 5.-Thermal emf of chromel $\mathrm{P}$ and of alumel vs platinum

\begin{tabular}{|c|c|c|c|c|c|}
\hline \multirow{2}{*}{$\begin{array}{c}\text { Tempera- } \\
\text { ture }\end{array}$} & \multicolumn{2}{|c|}{$\begin{array}{l}\text { Electromotive force } \\
\text { (reference junction } \\
\left.\text { at } 0^{\circ} \mathrm{C}\right)\end{array}$} & \multirow{2}{*}{$\begin{array}{l}\text { Tempera- } \\
\text { ture }\end{array}$} & \multicolumn{2}{|c|}{$\begin{array}{l}\text { Electromotive force } \\
\text { (reference junction } \\
\left.\text { at } 0^{\circ} \mathrm{C}\right)\end{array}$} \\
\hline & $\begin{array}{c}\text { Chromel } \\
\text { P-platinum }\end{array}$ & $\begin{array}{l}\text { Alumel- } \\
\text { platinum }\end{array}$ & & $\begin{array}{c}\text { Chromel } \\
\text { P-platinum }\end{array}$ & $\begin{array}{c}\text { Alumel- } \\
\text { platinum }\end{array}$ \\
\hline $\begin{array}{r}{ }^{\circ} \mathrm{C} \\
0 \\
50 \\
100 \\
150 \\
200\end{array}$ & $\begin{array}{c}\text { Millivolts } \\
0.00 \\
1.35 \\
2.81 \\
4.35 \\
5.96\end{array}$ & $\begin{array}{r}\text { Millivolts } \\
0.00 \\
-.67 \\
-1.29 \\
-1.78 \\
-2.17\end{array}$ & $\begin{array}{l}{ }^{\circ} \mathrm{C} \\
750 \\
800 \\
850 \\
900 \\
950\end{array}$ & $\begin{array}{c}\text { Millivolts } \\
24.60 \\
26.23 \\
27.83 \\
29.41 \\
30.98\end{array}$ & $\begin{array}{c}\text { Millivolts } \\
-6.63 \\
-7.08 \\
-7.52 \\
-7.95 \\
-8.37\end{array}$ \\
\hline $\begin{array}{l}250 \\
300 \\
350 \\
400 \\
450\end{array}$ & $\begin{array}{r}7.62 \\
9.32 \\
11.03 \\
12.75 \\
14.47\end{array}$ & $\begin{array}{l}-2.53 \\
-2.89 \\
-3.26 \\
-3.64 \\
-4.03\end{array}$ & $\begin{array}{l}1,000 \\
1,050 \\
1,100 \\
1,150 \\
1,200\end{array}$ & $\begin{array}{l}32.52 \\
34.05 \\
35.56 \\
37.05 \\
38.51\end{array}$ & $\begin{array}{r}-8.79 \\
-9.19 \\
-9.58 \\
-9.96 \\
-10.34\end{array}$ \\
\hline $\begin{array}{l}500 \\
550 \\
600 \\
650 \\
700\end{array}$ & $\begin{array}{l}\text { 16. } 21 \\
17.92 \\
19.62 \\
21.30 \\
22.96\end{array}$ & $\begin{array}{l}-4.43 \\
-4.85 \\
-5.28 \\
-5.73 \\
-6.18\end{array}$ & $\begin{array}{l}1,250 \\
1,300 \\
1,350 \\
1,400\end{array}$ & $\begin{array}{l}39.95 \\
41.35 \\
42.71 \\
44.04\end{array}$ & $\begin{array}{l}-10.70 \\
-11.06 \\
-11.42 \\
-11.77\end{array}$ \\
\hline
\end{tabular}

Tables 6 and 7 give the emf of chromel-alumel, chromel-platinum, and alumel-platinum at temperatures below $0^{\circ}$. Only two samples each of chromel $\mathrm{P}$ and alumel were used in determining these tables. The samples were taken from lots of wire giving 28.50 and -7.70 $\mathrm{mv}$ against platinum at $1,600^{\circ} \mathrm{F}$. The values of emf of the thermocouples and those of the individual elements against platinum were 
determined by calibration ${ }^{3}$ in a stirred liquid bath ${ }^{4}$ cooled by liquid air. A platinum-resistance thermometer was used as a standard for determining the temperature.

TABLE 6.-Thermal emf of chromel P-alumel, chromel P-platinum, and alumelplatinum at low temperatures

\begin{tabular}{|c|c|c|c|c|c|c|c|}
\hline \multirow{2}{*}{$\begin{array}{l}\text { Temper- } \\
\text { ature }\end{array}$} & \multicolumn{3}{|c|}{$\begin{array}{l}\text { Electromotive force (reference } \\
\text { junctions at } 32^{\circ} \mathrm{F} \text { ) }\end{array}$} & \multirow{2}{*}{$\begin{array}{l}\text { Temper- } \\
\text { ature }\end{array}$} & \multicolumn{3}{|c|}{$\begin{array}{l}\text { Electromotive force (reference } \\
\text { junctions at } 32^{\circ} \mathrm{F} \text { ) }\end{array}$} \\
\hline & $\begin{array}{l}\text { Chromel } \\
\text { P-alumel }\end{array}$ & $\begin{array}{c}\text { Chromel } \\
\text { P-platinum }\end{array}$ & $\begin{array}{l}\text { Alumel- } \\
\text { platinum }\end{array}$ & & $\begin{array}{l}\text { Chromel } \\
\text { P-alumel }\end{array}$ & $\begin{array}{c}\text { Chromel } \\
\text { P-platinum }\end{array}$ & $\begin{array}{l}\text { Alumel- } \\
\text { platinum }\end{array}$ \\
\hline $\begin{array}{l}{ }^{\circ} \mathrm{F} \\
0 \\
-10 \\
-20 \\
-30 \\
-40\end{array}$ & $\begin{array}{r}\text { Millivolts } \\
-0.68 \\
-.89 \\
-1.10 \\
-1.30 \\
-1.50\end{array}$ & $\begin{array}{r}\text { Millivolts } \\
-0.44\end{array}$ & $\begin{array}{c}\text { Millivolts } \\
0.24\end{array}$ & $\begin{array}{l}{ }^{\circ} \mathrm{F} \\
-160 \\
-170 \\
-180 \\
-190\end{array}$ & $\begin{array}{r}\text { Millivolts } \\
-3.68 \\
-3.84 \\
-4.00 \\
-4.15\end{array}$ & Millivolts & Millivolts \\
\hline $\begin{array}{l}-50 \\
-60 \\
-70 \\
-80 \\
-90\end{array}$ & $\begin{array}{l}-1.70 \\
-1.90 \\
-2.09 \\
-2.28 \\
-2.47\end{array}$ & -1.10 & .60 & $\begin{array}{l}-200 \\
-210 \\
-220 \\
-230 \\
-240\end{array}$ & $\begin{array}{l}-4.29 \\
-4.43 \\
-4.57 \\
-4.71 \\
-4.84\end{array}$ & -2.67 & 1.62 \\
\hline $\begin{array}{l}-100 \\
-110 \\
-120 \\
-130 \\
-140\end{array}$ & $\begin{array}{l}-2.65 \\
-2.83 \\
-3.01 \\
-3.19 \\
-3.36\end{array}$ & -1.69 & .96 & $\begin{array}{l}-250 \\
-260 \\
-270 \\
-280 \\
-290\end{array}$ & $\begin{array}{l}-4.96 \\
-5.08 \\
-5.19 \\
-5.30 \\
-5.41\end{array}$ & -3.03 & 1.93 \\
\hline-150 & -3.52 & -2.22 & 1.30 & $\begin{array}{l}-300 \\
-310\end{array}$ & $\begin{array}{l}-5.51 \\
-5.60\end{array}$ & -3.28 & 2. 23 \\
\hline
\end{tabular}

TABLE 7.-Thermal emf of chromel P-alumel, chromel P-platinum, and alumelplatinum at low temperatures

\begin{tabular}{|c|c|c|c|c|c|c|c|}
\hline \multirow{2}{*}{$\begin{array}{l}\text { Temper- } \\
\text { ature }\end{array}$} & \multicolumn{3}{|c|}{$\begin{array}{l}\text { Electromotive force (reference } \\
\text { junctions at } 0^{\circ} \mathrm{C} \text { ) }\end{array}$} & \multirow{2}{*}{$\begin{array}{l}\text { Temper- } \\
\text { ature }\end{array}$} & \multicolumn{3}{|c|}{$\begin{array}{l}\text { Electromotive force (reference } \\
\text { junctions at } 0^{\circ} \mathrm{C} \text { ) }\end{array}$} \\
\hline & $\begin{array}{l}\text { Chromel } \\
\text { P-alumel }\end{array}$ & $\begin{array}{l}\text { Chromel } \\
\text { P-platinum }\end{array}$ & $\begin{array}{l}\text { Alumel- } \\
\text { platinum }\end{array}$ & & $\begin{array}{l}\text { Chromel } \\
\text { P-alumel }\end{array}$ & $\begin{array}{c}\text { Chromel } \\
\text { P-platinum }\end{array}$ & $\begin{array}{l}\text { Alumel- } \\
\text { platinum }\end{array}$ \\
\hline $\begin{array}{l}{ }^{\circ} \mathrm{C} \\
0 \\
-10 \\
-20 \\
-30 \\
-40\end{array}$ & $\begin{array}{c}\text { Millivolts } \\
0 \\
-.39 \\
-.77 \\
-1.14 \\
-1.50\end{array}$ & $\begin{array}{c}\text { Millivolts } \\
0\end{array}$ & $\begin{array}{c}\text { Millivolts } \\
0\end{array}$ & $\begin{array}{l}{ }^{\circ} \mathrm{C} \\
-110 \\
-120 \\
-130 \\
-140\end{array}$ & $\begin{array}{r}\text { Millivolts } \\
-3.78 \\
-4.05 \\
-4.32 \\
-4.57\end{array}$ & Millivolts & Millivolts \\
\hline $\begin{array}{l}-50 \\
-60 \\
-70 \\
-80 \\
-90\end{array}$ & $\begin{array}{l}-1.86 \\
-2.21 \\
-2.55 \\
-2.87 \\
-3.19\end{array}$ & -1.20 & .66 & $\begin{array}{l}-150 \\
-160 \\
-170 \\
-180 \\
-190\end{array}$ & $\begin{array}{l}-4.81 \\
-5.03 \\
-5.24 \\
-5.43 \\
-5.60\end{array}$ & -2.95 & 1.86 \\
\hline-100 & -3.49 & -2.20 & 1. 29 & -200 & -5.75 & -3.36 & 2. 39 \\
\hline
\end{tabular}

${ }^{3}$ Acknowledgment is made to D. O. Burger for making these calibrations.

4 BS J. Research 6, 401 (1931) RP284.

Washington, December 19, 1934. 